ETO: $81 ’ 276.3-055.2$

ORIGINAL SCIENTIFIC PAPER

808.51

81 '373.612.2

DOI: 10.19090/hk.2019.4.92-107

\author{
KATONA Edit \\ Újvidéki Egyetem, Bölcsészettudományi Kar \\ Magyar Nyelv és Irodalom Tanszék \\ Újvidék, Szerbia \\ katonae.zenta@gmail.com
}

\title{
MINEK NEVEZZELEK? A METAFORAHASZNÁLAT GENDERALAPÚ VIZSGÁLATA SZÓNOKI BESZÉDEKBEN $^{1}$
}

\section{What shall I call you? Gender-based analysis of metaphor usage in oratory speeches}

\section{Kako da te zovem? Rodna analiza upotrebe metafore u besedništvu}

A társadalmi életben számos alkalom adódik, amikor beszédet kell mondani. Az ünnepek, társadalmi események alkalmával elhangzó beszédek is legtöbbször a meggyőzés, legalábbis a hatáskeltés szándékával készülnek. Dolgozatomban húsz szónoki beszédet vizsgálok meg: tíz nő és tíz férfi beszédét. A beszédek fele közéleti fórumokon hangzott el, tíz pedig az egyetemisták számára Budapesten hagyományosan megrendezésre kerülő Kossuth-szónokversenyen. A kitüzött cél annak feltérképezése, mely képzetkörökből származó metaforákkal élnek a közéleti szereplők és az egyetemisták, vajon van-e markáns különbség a nők és férfiak, politikusok, más közéleti beszélők és egyetemisták beszédeinek képi jegyeiben. Különös figyelmet érdemel, befolyásolja-e a képek megválasztását, ha csupán a saját nemük képviselőiből álló közönséghez intéznek beszédet a szónokok. Nem lényegtelen szempont az sem, a metaforikus jelleg a tágabb szövegkörnyezet eredménye, kognitív alapokon nyugszik, vagy nyelvi-stilisztikai formát is kap, s hogy milyen retorikai eljárások révén épül be a beszédekbe.

Kulcsszavak: beszédhelyzet, nemi szerep, logosz-pátosz-ethosz, kognitív metafora

\footnotetext{
${ }^{1}$ A tanulmány a Szerb Köztársaság Oktatás- és Tudományügyi Minisztériumának 178017. számú projektuma keretében készült.
} 


\section{Bevezetö}

A kezdeti próbálkozások után a XX. század utolsó évtizedeire szárba szökkent, majd kivirágzott a gendernyelvészet. A nemi alapú vizsgálatok feltárták a férfi- és női beszéd közötti különbségeket a beszédmódokra, a szövegek lexikai és grammatikai stilisztikai jegyeire, a nyelvi képességekre, a verbális memóriára vonatkozóan. A szónoki beszédek szempontjából nem lényegtelen utalnunk arra, hogy az amerikai kutatások szerint (vö. Tóth 2012) a férfiak az általános megállapításokra, a tényekre koncentrálnak, míg a nők beszédében az érzelmi vonatkozások és a részletek kidomborítása a hangsúlyos.

A szövegek képi anyagának vizsgálatakor kicsúcsosodó következtetés, miszerint a gazdasági és médiaszövegek az ún. „férfimetaforák” túlsúlyáról tanúskodnak, kiterjedt kutatások eredménye, így a valóságértékét nem vitathatjuk. Nyilvánvaló ugyanis, hogy a gazdaságot, a médiát a férfiak uralták/ uralják, s így annak frazeológiai anyagát, metaforarendszerének kialakulását nagymértékben befolyásolják. Ugyanakkor a kép árnyalására mindenképp szükség van. Egyfelől mivel a metafora az emberi gondolkodás leképezése, a világot ősi mítoszokon, testi, térbeli tapasztalatainkon alapuló sémák nyomán értelmezzük, ily módon minden ember közös kincse, akár kognitív alapon levezethető metaforákról, metaforikus kifejezésekről, akár a metafora stilisztikai megnyilvánulásairól beszélünk. Másfelől amellett, hogy az elmúlt évtizedekben jeles (közismert és kevésbé közismert) nők beszédeit elemzik, fölmerült az a kétségtelen szempont, hogy a gyereknevelés során ősidők óta a nők alakítják ki gyermekeik erkölcsi ítéleteit, szókincsét, beszéd- és viselkedésmódját, tehát a dajkák, az anyák (és általában a szülők) nevelői, tanítói „,mintaadó” szerepe (ahogy Quintilianus figyelmeztet rá) el nem hanyagolható: „Nemcsak az apákról beszélek, hiszen tudjuk, hogy a Gracchusok ékesszólását nagyban elősegítette anyjuk, Cornelia, akinek igen kimüvelt stílusa még az utókorra is fennmaradt levelek formájában" (idézi Pölcz 2018, 22).

\section{A kutatás adatai, elvárásai}

A beszédek nemi alapú elemzése az utóbbi időben terjedt el, noha a gendervizsgálatok már több évtizede folynak, és az elmúlt időszakban kiterjedtek a meggyőzési folyamat számos tényezőjére: a befogadásra, a meggyőzhetőségre, a konformitásra, a döntéshozatal morális tényezőire. Az eredmények igen ellentmondóak, talán a morális döntéshozatalra vonatkozóan tehetünk viszonylagos bizonyossággal egyértelmű megállapításokat, hiszen még abban 
a vonatkozásban se lehet egység, hol mi számít női vagy férfitémának. A téma további tudományos elemzése elött még nagy jövő áll, különösen a kognitív metaforák tekintetében.

Mivel magam is kutattam már a metaforahasználatot középiskolás diákok, egyetemisták (Katona 2006, 2009, 2012), valamint a férfibeszéd metaforáinak sportnyelvi összefüggéseit (Katona 2016), érdemesnek találtam vizsgálódni a tekintetben, vajon megmutatkoznak-e az általános megállapítások a mai magyar nyelvü (eredeti és fordítás)szövegekben. Tóth Gabriella angol nyelvü médiaszövegekből vonta le inkább stilisztikai, mint kognitív alapú következtetéseit (Tóth 2012).

Dolgozatomban húsz szónoki beszédet vizsgálok meg: tíz nő és tíz férfi beszédét. A beszédek fele közéleti fórumokon hangzott el, tíz pedig az egyetemisták számára Budapesten hagyományosan megrendezésre kerülő Kossuthszónokversenyen. A beszédek komplex bemutatására nem vállalkozom, az egyetemisták beszédeinek egy részét, a lelőhelyükként szolgáló kiadványokban egyébként is retorikai elemzésnek vetik alá, csupán a témámat érintő jellegzetességekre térek ki.

A közéletben ma már találkozhatunk női szónokokkal: nagykövettel, női rabbival, intézményvezetôvel, művésszel, hírességgel, médiaszemélyiséggel. Az azonban egyértelmű tényként szögezhető le, hogy a nők közéleti beszélőként leggyakrabban a nemüket érintő témákat taglalják, nehezen lehet rábukkanni egy gazdasági fórum megnyitóján elhangzó női üdvözlőbeszédre. Így egyik témaként egyértelmúen a nőkről szóló beszéd kínálkozott: Bogyay Katalin állandó ENSZképviselő, Oprah Winfrey színésznő-müsorvezető, Emma Watson színésznő, az ENSZ jószolgálati nagykövete, Colleen Bradley Bell amerikai nagykövet a nők sorskérdéseire koncentráló beszédei kerültek a korpuszba. Közülük Emma Watson kimondottan a férfiakat szólítja meg. A közéleti beszélők anyagához illeszkedve a Kossuth-szónokverseny anyagából is hat nemi témájú beszédet jelöltem ki. A verseny mottóját az alábbi Kossuth Lajos-idézet szolgáltatta: „A hölgyek játszva többet tehetnek, mint küzdve mi: Ők egy körtánccal a magyar táncot, egy dalocskával a magyar népdalt, egy beszélgetéssel a magyar nyelvet divattá tehetik. A divat hatalmasabb, mint logika" (Kossuth Lajos).

A beszédek másik csoportja ünnepi, főként kulturális vagy politikai események alkalmával hangzott el: a 2010-es könyvhét megnyitóján (Bán Zsófia), könyvvásáron (Göncz Árpád), a nők világkongresszusán (VI. Pál pápa), irodalmi évfordulón (Áder János), szilveszterkor (Mácsai Pál), nemzetközi konferencián (Donald Tusk). Ehhez társulnak az egyetemistáknak a könyv szerepét, a bölcsesség és ékesszólás jelentőségét megfogalmazó szónoklatai. 
Ha a beszédfajták felől közelítjük meg a kérdést, a közéleti beszédek leginkább az ünnepi beszéd jegyeit hordozzák, vagy politikai beszédek. A politikai beszéd pedig tulajdonképpen a tanácsadó beszéddel áll átfedésben (vö. Adamikné 2014, 38). Az egyetemisták beszédei változatos müfaji besorolásúak, jobbára a tanácsadó beszéd kategóriájába tartoznak, de ünnepi beszédek, vádbeszéd jellegủ szónoklatok is vannak, sőt gyászbeszéd is akad.

\section{Közéleti-politikai metaforahasználat}

A retorika a vád- és védőbeszédek köréből indulva később a politikai beszédek területén lombosodott ki. A politika sok ünnepi beszéd elmaradhatatlan tartozéka ma is, így az ünnepi beszédek metaforakincse is gyakran épül rá.

A metafora a politikai beszédekben régtől fogva jelen van, „felidéző erővel ruházza fel a beszédeket, közösen asszociált kulturális mintákat hív elö, és átélhetővé, élményszerüvé teszi a közlést" (Aczél 2009, 140). A nagy politikusokra jellemző beszédek kognitív alapjait és szociokulturális beágyazottságát vizsgálva megállapítható, ki mely mítoszokra épít. Churchill a heroizmusra fókuszál, és az utazásmetafora révén határozza meg a célhoz, a győzelemhez vezető utat, a kor közösségi feldolgozását, az események megélését, a túlélés lehetőségét. Az ellenség legyőzését a fény és sötétség metaforikus alkalmazásával éri el. Blair, aki az etiko-politika nyelvének a létrehozója volt, amerikai példa nyomán a létrehozás, az alkotás metaforáira tér át, míg a Vaslady, Margaret Thatcher beszédeiben az ipar a harc területeként tünik föl, a társadalmi problémák ellenségként. Aczél Petra a magyar politikusok beszédeiben is kimutatja az utazásmetafora jelenlétét: „,vitorlát bont, viharos vizeken járunk” (vö. Aczél 2009, 140-142).

\section{A nőkről szóló beszéd metaforái}

A nők és férfiak társadalmi szerepéről vallott nézetek ősidők óta jelen vannak az emberi gondolkodásban, a genderalapú vizsgálatok hozták előtérbe a nemek beszédében való különbségek tematizálását. A tudományos kutatást megelőző naiv magyarázatok is tanulságosak számunkra, mivel ezek „,sokszor költőiek, különösek, de mindig tanulságosak, hiszen fényt vetnek arra, mit gondoltak az adott korszak emberei a nyelvről és a társadalomról, a nőkről és a férfiakról, tevékenységükről, céljaikról és feladataikról” (Huszár 2009, 13). A szónoklatok elemzése is ilyen tanulságokkal jár.

A közéleti nők mai beszédeikben leggyakrabban az egyenjogúságra, az esélyegyenlőségre, a nőkben lakó erőre, az ellenük elkövetett erőszakra hivat- 
koznak. Mindegyikük személyiségjegyei kibomlanak a beszédekben, s szinte mindenki a családja és a maga élettényeire utal bizonyító erővel, vérmérsékletétől és pozíciójától függően. Az egyetemista hölgyek érdekes retorikai szituációkat választottak: egyikük a kiegyezés korába visszahelyezkedve hívja össze barátnőit, két másik szónok egy-egy XXI. századi konferencia megnyitóbeszédét írja, egyikük csupán női közönséghez fordul. A fiúk általában a Hölgyeim és Uraim! megszólítást választják, de nem ritka a kikacsintás a férfi vagy női közönség irányába: „Hölgyeim, én bevallom, ha reggelente [...] meglátok az óriásplakáton egy kedvesen mosolygó, csinos kis tucatarcot hosszú hajjal és többnyire fedetlen vállakkal, elöször is illedelmesen visszamosolygok", a férfiak egyetértésére való célzás: „én meg elfelejtem azt a néhány cinkos mosolyt azoktól, akiknek az imént láttam az arcán" (Száraz 2003, 99).

A férfibeszélők részéről negatív jellegü megjegyzés a nőkkel kapcsolatban legfeljebb csak azért hangzik el, hogy azt cáfolják, így az imént idézett szónok Püthagorasz tézisét: „A jó princípiuma teremtette a rendet, a fényt és a férfit, a rossz princípiuma a káoszt, a sötétséget és a nőt" (Száraz 2003,98) csak azért hozza szóba, hogy elüsse ezt a nézetet.

A közéleti női beszélők a nők megpróbáltatásait teszik szóvá, így a bírálat az ő szónoklataikból nem maradhat el, s kritikájuk elsősorban a férfiak ellen vagy az általuk uralt társadalmi közeg ellen irányul. A semmibevétel bizonyítására A NŐ TÁRGY/TESTRÉSZ metaforát emelik ki: „14 éves koromban a sajtó elkezdett szexuális tárgyként kezelni” - mondja Emma Watson, Collenen Bell fölpanaszolja, hogy egykori munkatársa igen sajátos metaforával élt a kolléganőit illetően. Sommás véleménye így hangzott: „A NŐK IRODARÉSZLEGE PETEFÉSZEKDZSUNGEL" (Bell 2015). Vagyis a nőket azonosítja egy testrészükkel. Önkéntelenül eszünkbe juthatnak a szlengből ismert hasonszőrü durva azonosítások.

A női politikusok, akik a női erőre hivatkoznak, A NÖ ÉPÜLET metaforára alapoznak: ,,a nők erős pillérei a béketörekvéseknek és nélkülözhetetlen kulcsszereplői a békés és befogadó társadalmak megteremtésének" (Bogyay 2017). Nincs ez másképp az egyetemisták beszédeiben sem: „Kedves Sorstársaim! Nők, akik a társadalom építőkövei, az új társadalom tanítómesterei vagytok" (Köble 2003, 169). A nők nőkhöz intézett beszédeiben a megszólítások is a sorsközösségre utalnak: Kedveseim! Barátnéim! Sorstársaim! Az egyetemista lányok a nők teremtő-, megtartó erejét, feladataik összetettségét említik föl, a buktatókra is utalnak: „Üzletasszonyként, divattervezőként, tanítóként, tudósként is megállja a helyét... Saját börünkön tapasztaljuk a szólásmondás igazságát, miszerint két lovat egy fenékkel nem lehet megülni” (Köble 2003, 169). 
A NŐ KÖZVETÍTÖ/nemzetfenntartó, összetartó ERÖ. Az egyetemisták nagy erővel jelenítik meg ezt a kognitív metaforát a családanya személyes szerepvállalásáról: „Jelen voltak [...] a férjeiket, szerelmeiket a valódi és jelképes csatamezőkről rendületlenül hazaváró mater familiasként. A pártpolitikai alapon széttöredezett családok összetartóiként” (Szontagh 2003, 88); „Véren át és lelken át, testtel és testhez érve, búzacsíra fölé hajolva, vagy éppen ünnepi gyertyát gyújtva" (Gáti 2003, 154) képzelik el a lányok a nemzeti hagyomány, a népköltészeti kultúrkincs továbbadását. Beszédeikben összefonódik személyes, női és nemzeti sors: „Bízvást állíthatom, hogy egy magunkfajta nő többet tehet magyar hölgyként, mint egy külhoni császárné" (Gáti 2003, 153).

A gondoskodás, odaadás, amiről például a pápa levelében is olvashatunk az egyetemista lányok beszédeiben is fölbugyog, anélkül, hogy lemondanának a jogaikról. Tisztában vannak a túlpörgő, elidegenedő, elgépiesedő kor kihívásaival, de vállalják a bájt, a kellemet, a kecsességet, a divat követését, még a hiúságot is, a helytállás nehézségeit sem hallgatják el: „Igaz, ma a női emancipáció korát éljük, s a nő mindenben egyenrangú akar lenni a férfival. Ám teljesen nem hazudtolhatja meg önmagát" (Dósa 2003, 149-150). Néhol némileg ellentmondásos kép alakul ki a női szereppel kapcsolatban, mintegy bevillan a sztereotip nő-férfi fölfogás: „Hiszen a gyermek legföképp az anyjától tanul: apai ész és anyai szív vezérli” (Gáti 2003, 154).

A politikusnők hangja élesebb és harcosabb, az érdekérvényesítésre koncentrál. Oprah Winfrey a maga eszmélési folyamatán keresztül érzékelteti a nők felemelkedésének lehetőségét, sok érzelmet fölvonultató hatásos beszédében a több szövegben is föllelhető nappal-éjszaka metaforára is hivatkozik: „Legnagyobb erősségük abban rejlik, hogy képesek reménykedni, és azt érezni, hogy még a legsötétebb éjszaka után is egy szebb nap jön" (Winfrey 2018). Beszéde a legközismertebb kognitív metaforákra épül: AZ ÉLET UTAZÁS, AZ ÉLET KÜZDELEM, A NÖ AZ ERÖ FORRÁSA.

A NÖ CÉL/motiváló ERÖ. A fiú egyetemisták sem mentesek beszédeikben a személyességtől, mikor a nőket dicsérik, a fiúk a nők nélkülözhetetlenségét nagy vehemenciával bizonygatják, különösen, ha egymást szólítják meg: „Uraim! Nagy bajban vagyunk. Büszkén vállalva azt, amivel a férfiúi lét jár, kijelenthetem, hogy semmire se mennénk nők, hölgyek nélkül. Semmire, mert már cél se lenne előttünk..." (Dudás 2003, 107). Az egyik egyetemista a csodával azonosítja a másik nemet, miattuk történik minden, egy másik a racionális érveket fölöslegesnek is tartja, a másságát hangsúlyozza: „és mert egész egyszerúen imádnivaló, és homlokegyenest más, mint mi: olyan puha" (Száraz 2003, 99). A nők mindenhatóságának bizonyítéka két fiú esetében is, 
hogy akár az öltözékükre is odafigyelnek a nők miatt: „És újragombolom az ingemet, most már helyesen, és megigazítom a nadrágszáramat. No, nem mintha egy óriásplakátnak szeretnék tetszeni, de azért mégis" (Száraz 2003, 99); „Mert a nő több, mint csoda. A nő több, mint logika. Cél. Fény. Irányítás. S így jó élni is. Még öltönyben is" (Dudás 2003, 108).

ANŐ ÉS FÉRFI EGY EGÉSZ. A nő és férfi egymáshoz való viszonyát ábrázolva az egyik egyetemista lány a világfa képét festi fel, amelynek csúcsán egyik oldalt a NAP, A FÉRFI, a másik oldalt A HOLD, A NÖ foglal helyet. „Ha azt szeretnénk, fánk virágba boruljon, s gyökerei ne száradjanak el, szükség van a Nap sugaraira és a Hold fényére" (Dósa 2003, 150), hisz sugaraik egymást váltják. Szerzőnk idézi a mondókákat, a népmeséket, szívesen emlékszik vissza olyan kedves megjegyzésekre, hogy a nagymama a Világszép Nádszálkisasszonyhoz hasonlította, de a férfival való kiegészülés, egység fontosságát is elengedhetetlennek tartja: „Látod, kislányom, te is ilyen nádszálkisasszony vagy, de a királyfival együtt kősziklaként küzdhettek" (Dósa 2003, 149). II. János Pál levelében szintén utal a két nem egymást kiegészítő szerepére: „A női és férfi mivolt nemcsak fizikai és pszichikai, hanem ontológiai szempontból is kiegészítik egymást. Csak a »férfias « és »nőies« kettősség valósítja meg teljesen az »emberit«" (II. János Pál 1999).

II. János Pál, aki levelében a világ összes nőjét kívánja megszólítani, a nőkkel kapcsolatban a hála, a méltóság, a szolgálat, az odaadás, az érzelmi, kulturális és lelki anyaság fogalmát, a női géniuszt emeli ki; hangsúlyozva a nők érdemeit az élet minden terén a szociális-etikai dimenziókra célozva alkot az egyházi mércéket és a modern élet kihívásait egyesítő beszédet a nőről, „aki talán jobban látja az embert, mint a férfi, mert a szívével lát". Különösen megindító stilisztikai értelemben is kifejtett metaforája: A NÖ ISTEN MOSOLYA: „aki a világra jövő gyermek számára Isten mosolyává leszel” (II. János Pál 1999).

\section{Az ÉLET konceptualizálódása a kognitív metaforákban}

Sok beszédet elolvastam, míg válogattam, az élettel kapcsolatosan frazeologizálódott metaforákkal, aforizmákkal mindegyikben találkoztam, ezek egy része olyan mértékben konvencionalizálódott, hogy joggal illik rájuk a halott metafora kifejezés. A kommunikáció részévé váltak, nem tudunk megszólalni nélkülük, annyira mindennaposak, de könnyen asszociálunk a jelentésükre különböző kultúrák bölcsességeit hallva is: Az egész világ egy keskeny híd, vagy: útvesztöbe kerül, utad volna, s ösvényt keresel. 
A haladást a közismert AZ ÉLET ÚT/UTAZÁS szerkezeti metaforára építik a nők, férfiak, közéleti beszélők, egyetemisták és természetesen mi magunk is a mindennapi beszédben, nem tesz másképp a pápa sem: „látván a sok akadályt, mely a világ különböző részein annak útjában áll, hogy a nőt sajátos méltóságának megfelelően elismerjék, tiszteljék és megbecsüljék... Ezen az úton tovább kell menni!” (II. János Pál 1999); , ,akik erőt adtak nekem az úton, amelyek a végén most itt állhatok” (Winfrey 2018); „Mi vagyunk azok, akiknek a ránk nehezedő sokféle követelmény miatt gyakran kell megtalálnunk a saját utunkat... Van négy gyerekem, van karrierem, s van barátokkal teli magánéletem. Az én utam se volt nyílegyenes..." (Bell 2015). A KARRIER FUTÓSZALAG a gyártási folyamatok, az alkotás világába vezet már. Az alkotótevékenységre való célzásként a MUNKA VERSENYFUTÁS kognitív metafora révén biztatja a férfiakat segítésre Emma Watson: „Szeretném, ha a férfiak is felvennék a stafétát” (Watson 2014).

Egy egyetemista lány szónoklatát egy képzeletbeli hajó matrózaihoz intézi, a megszólítás is ennek megfelelő: „Matróztársaim!” Egész beszédét ennek az allegóriának a jegyében tartja, például mikor a szónoklat tézisét kifejti: „A történetek nemcsak a Hajóról szóltak, hanem a kapitányról, hiszen Ékesszólás Bölcsességgel együtt az Emberi Élet kormányzója. Az Emberi Élet törékeny, a legtörékenyebb hajó.” A sok hullámot látott ladik lezüllése kapcsán az is fölmerül benne: vajon az „Emberi Élet a legcsodálatosabb, legfenségesebb, legnemesebb hajó a tengeren, vagy nem más, mint egy lukas ladik egy részeg tengerésszel" (Szökrön 2018, 196).

„A cél halál, az élet küzdelem, / S az ember célja e küzdés maga”, állítja Madách, s nincsenek ezzel másképp a szónokok sem. Az élet küzdelemjellege bontakozik ki annak a hallgatónak a beszédében is, aki Andrássy gróf feleségeként aggódó levélben hívja össze barátnőit Erzsébet királyné hatása, ténykedése miatt. A nemzeti érdekek pusztulása és a személyes veszteség kapcsán írja: „küzdelem ez, melyben csak mi lehetünk a vesztesek”. A magyar nagykövet beszédéből sem maradhat ki AZ ÉLET KÜZDELEM metafora: „A fegyveres konfliktusok mellett a nőknek számos egyéb veszéllyel kell megbirkózniuk" (Bogyai 2017). Mácsai Pál szilveszteri beszédében a kor emberének hívságait, a mulandóságot, az iszapbirkózás nehézségeit vázolja fel a Kurt Vonnegut által lidércnyomásnak titulált huszadik században, közben mintegy mellesleg a viszonylagosságról szólva elsüt néhány lesújtó metaforát talmi értékeinkkel kapcsolatban is: „Ahogy mi mosolygunk a romantika ábrándján, úgy fognak ők mosolyogni a mi sorozatgyártású kultúránkon, múanyag javainkon, önmagunkkal folytatott iszapbirkózásunkon" (Mácsai 2000). 
A dolgozat elején idézett kutatások szerint a férfiak beszédei a nagy, általános metaforákra épülnek, és a nagyobb távlatok felvillantásától sem idegenkednek. Áder János például A TÖRTÉNELEM UTAZÁS/KÖZLEKEDÉS (térben és időben) metaforával indítja Arany János ifjúságának bemutatását: „Mire felnőtté válik, a haza és haladás programja új pályára igyekszik állítani Magyarországot". A küzdelmes éveket AZ ELNYOMÁS CSEND metafora fémjelzi: „Arany János megéli a Világos és Arad utáni élet kínzó fájdalmát, a fagyott várakozást, a Bach-korszak passzív némaságát”. AZ ÉLET TERMELÉS jellemzi a küzdelmes éveket, a fejlődést: „Lám, hova jutott Magyarország e termékeny, mozgalmas és igen zsúfolt két emberöltő alatt.” A TÖRTÉNELEM VÁLLALKOZÁS metafora zárja a beszédet: „részesévé vált a 19. század nagy vállalkozásának: A magyar nemzet újjáalapításának". Így állítja párhuzamba a kor leírását Arany életének bemutatásával.

Író emberről beszél, Arany tevékenységének jelentőségét A SZÓ FEGYVER ÉS GYÓGYSZER metaforák támasztják alá. Mondatpárhuzamait így kezdi: „Aki a döblingi csendet megtörő Széchenyitől kapott erőt, hogy bátran leírja: Király, te tetted ezt!" A nyelv éltető erejére utaló anaforás mondatsor második érve pedig a gyógyszermetafora: „Hogy hétköznapi harcaink fület és lelket sértő hangjaira sokszor gyógyír a szép magyar vers.” Mindez persze csak úgy érhető el, ha tanulmányozzuk is Arany költészetét: ,Születésének 200. évfordulóján érdemes közelebb lépnünk hozzá" (Áder 20017), hisz AZ ELMÉLYÜLT GONDOLKODÁS HALADÁS (jelesül: járás).

\section{A szellemi értékek konceptualizálódása a kognitiv metaforákban}

Áder János fent említett ünnepi beszéde már ötvözi AZ ÉLET KÜZDELEM és A SZÓ FEGYVER/ERÖ metaforát. A korpuszban összesen nyolc szöveg alapmotívuma a kultúra, a könyv, a szó, a bölcsesség. Az egyetemisták szónokversenyén egyik évben mottóul szolgáló Vörösmarty-idézet: Ment-e könyvek által a világ elébb? témájára írt szónoklatok közül öt került a korpuszba, egy egyetemista beszéde a szónoklás és a bölcsesség elsődlegességét hirdető témát dolgozta fel. A közéleti beszédek közül Göncz Árpád Frankfurti Könyvvásáron mondott, Bán Zsófia 2010-es könyvheti megnyitóbeszéde, Donald Tusk konferenciamegnyitója kötődik még ehhez a témához. Mácsai Pál egy Fodor Ákos-versidézettel adózik a szó szépségének.

A kultúrához (könyvhöz, retorikához) kötődő retorikai szituációk: az írói évforduló, a könyvhét, a könyvvásár, az egyetemisták részéről választott szituációk: egy könyvkiadó megnyitóünnepsége, magától értetődően hozzák maguk- 
kal a könyv, a szó szerepének a középpontba állítását. A könyvről szólva az egyetemisták az esztétikai jellegére is utalnak, de az olyan érzéki vonatkozásokat sem hanyagolják el, mint az illat, a tapintás, az olvasáserotika, például: „Érezzétek a régi és frissen kiadott könyvek finom illatát, a betűk varázsát” (Földesi 2001, 91).

A szónokok előbb előkészítik a témát: „Tudom, most sokakban felmerülhet a kérdés, hogy mi az a megváltó szó" (Boros 2001, 94), majd egyöntetủ véleményüknek adnak hangot, miszerint A KÖNYV/A SZÓ KINCS/TÁRHÁZ/ KÖZVETÍTÖ: „Megalkotta a könyvet, ami az emberi értelem kimeríthetetlen tárházának bizonyult" (Boros 2001, 94). A szerző kicsit tovább is gondolja a témát, mert a minőségválságra utalva jelzi, ún. „kaptafa” könyvek is kielégíthetnek egyes olvasói igényeket. A fentebb idézett Földesi Norbert első díjas szónoklatában felvázolja a technika vívmányainak betörését a kultúra és tudomány minden területére, de továbbra is hisz a könyv közvetítő szerepében, varázsában, a tudás tartósítóját, a fantázia felébresztőjét ünnepli benne: „A tudás közvetítésének az eszköze ma is a könyv lehet" (Földesi 2001, 90); Szőnyi László Gyula, aki Móricz Zsigmond Ady Endre ravatalánál mondott beszédének mintájára írta meg szónoklatát („Költő fekszik a ravatalon.” - „Egy könyv fekszik a ravatalon"), mintegy gyászbeszédet mond a könyv felett, amely nem érdemli meg ezt a sorsot, hisz „a könyvek is ösztönzői [...] találmányoknak” (Szőnyi 2001, 120). Vádló retorikai kérdéssora végén a könyv föltámadását is megjósolja.

Bán Zsófia nagy hatású, retorikailag kitűnően fölépített, metaforahálóval átszőtt beszédében (Bán 2010) összefüzi, kibontja, továbbgondolja a korábbi metaforákat, újakat alkot, kognitív értelemben és stilisztikai vonatkozásban egyaránt. Miután jelzi A SZÓ TETT jellegét, A KÖNYV KINCS/ TUDÁSHORDOZÓ/TÖRTÉNELEMMEGÖRZÖ mivoltára irányítja a figyelmet: „A könyv a kultúra, a társadalom, az emberiség családi fényképalbuma”, majd Füst Milán szavait parafrazeálva ad nyomatékot megállapításainak: „ez mind mi voltunk egykor". Ezzel mintegy kétségbevonhatatlanná teszi a könyv és a szó jelentőségét, de nem riad vissza a mindennapiságot árasztó, A KÖNYV CSIRIZ metaforától sem: „A könyveket mindenáron meg kell őrizni, mert nélkülük nincs közös emlékezet, amit, ha úgy tetszik, lehet történelemnek hívni, de lehet egyszerüen úgy is gondolni rá, mint a ragacsos csirizre, ami az eddig történteket, az eddig megesett cselekedeteket tartja össze és teszi értelmezhetővé."

Legszemléletesebb képi anyaga azonban nem is az erényekre, hanem a negatív festésre építkezik, az anyagi és gazdasági vonatkozások eluralkodásának a negálására: „Ülünk önelégülten a kincseinken, és azt képzeljük, hogy csak 
papír, nyomdafesték, áfa meg adókulcs, és nem gondolunk arra, hogy ha ez nincs, akkor nincs semmink, akkor a semmi áfáján ülünk". Gondolatmenetének lezárása semmi ágára való asszociálás lehetőségét felkínálva gyakorol megrázó hatást a befogadóra. Bán Zsófia a kellemetlen, nemkívánatos negatív társadalmi jelenségeket az időjárás ártalmaival varázsolja elénk: „,valami betegséget hordozó undok széljárás a tudatlanság”, a szavak „kasból elszabadult méhek”-ként tünnek föl. AZ ARANYALAPOK A KÖNYVEK, állítja bizton a szerző, s a szavak hatását kiterjeszti a jog és erkölcs vonalára, mert csak a szavak jó értelmezése vezethet el a jogrendig, az erkölcsös magatartásig. A SZÓ MÁGIKUS ERÖ, de KÉTÉLÜ FEGYVER is, ám csak a szavak könyvekböl levont jelentése eredményezheti a megértést. Míg ez nem történik meg, ,addig csak hajléktalan szavak keringenek a levegőben" (Bán 2010), zárja a következtetésrendszert ismét természeti vonatkozások beemelésével a szerző. Az időjárás a beszédében társadalmi, szellemi jelenségeket megjelenítő kognitív metaforaként tünik fel.

Göncz Árpád beszéde szintén a könyv ünnepén, a Frankfurti Könyvvásáron hangzott el. Amikor államelnökként egy idegen ország piacán kínálja a magyar kultúra termékeit, a kultúrából, nyelvből, annak természetéből adódó különbözőségekre tér ki, ugyanakkor az emberi szellem egyetemességét állítja ezzel szembe, amely mindig nyitott a világ tükröződésére, $\mathrm{s}$ ez a tükör lehet a magyar író szemléletét sugárzó könyv a befogadó számára: „Amire most ő csodálkozik rá s - remélem - szereti meg ezt a másfajta világot a mi szemünk tükrében.” A KÖNYV TÜKÖR kognitív metafora mintegy betetőzése annak a gondolatmenetnek, hogy az idegen közegben a KÖNYV ugyan ÁRU, de ugyanakkor ÉRTÉK és KALAND is: „A jó hírünk záloga tehát, ha a portékánk - szavakká formált világunk: az anyanyelvünk irodalma - a vevő számára érték." AZ OLVASÁS SZELLEMI KALAND-ja révén a különbözőségben föllelt azonosság felfedezése is fémjelzi a maga életében is megtapasztalt igazságot: A SZÓ HATALOM: ,aki idestova harminc éve tapasztalja a szó hatalmát, igyekszik annak hasznát venni, s a hitelét maga is gyarapítani” (Göncz 1999).

A SZÓ FEGYVER/ERŐ kognitív metafora az ókortól Donald Tusk beszédéig benne van a köztudatban. Donald Tusk politikai beszéde a történelemböl indul ki, de a szöveg keretét alapvetően a szó erejébe vetett hit adja. Az elején jelzi: „a darwini politikai küzdelemben a leghatásosabb fegyver a szó, és ez mindig így volt, és így is lesz". A folytatásban az örömhírhozó (evangélista) politikus, a faként lombosodó Európa képe tárul fel, végül a keretet alkotó elem a szó ereje: „Talán e szavak nem eléggé csattanósak a Twitter-politizálás korában. De rám nagy hatással van a bennük rejlő igazság és erő" (Tusk 2017). 


\section{Összegzés}

A dolgozat a nemek metaforahasználatának vizsgálatát tủzte ki célul elsősorban két téma: a női szerep és a kulturális értékek (könyv, szó, bölcsesség) kapcsán. Női beszédeket találni ma is sokkal nehezebb, a nők ma is kevesebben foglalkoznak politikával, kevésbé vannak jelen a gazdasági életben. Egyes kutatások szerint a nők közül sokan idegenkednek is a nyilvános szerepléstöl, szoronganak, úgynevezett imposztorszindrómától szenvednek (vö. Dér 2018). Csak reménykedhetünk abban, hogy a nők társadalmi megítélésének megváltozása folytán a helyzet jobbra fordul. A dolgozatban megjelenő közéleti szereplők s a szónokversenyeken nagy számban jeleskedő lányok táplálják ezt a hitet.

A kulturális metaforákkal kapcsolatos nagy korpuszú vizsgálatok megállapításai szerint ,a metaforikus nyelv [...] egy kulturális csoport megismerő tevékenységét jellemzi” (Baranyiné 2018), tehát nem egyéni találmány (a költészet ad lehetőséget a szemantikai ugrásokra), egyéni választás annyiban létezik, hogy mindenki maga dönti el, hogy a kialakított metaforakincsből mit emel ki. Univerzális és eltérő metaforák is megtapasztalhatók a különböző kultúrákban. A dolgozat, mely kis korpuszanyagánál fogva holmi egyetemes megállapításokra nem vállalkozhat, szintén ezt bizonyítja.

Egyes egyetemesnek tekinthetó (az életre, szellemi értékeinkre vonatkozó) metaforáink épp a kulturális beágyazottság révén mindkét nem beszédeiben tartalomszervező elemként jelentkeznek, közéleti beszélőknél és egyetemistáknál, külföldieknél és magyaroknál egyaránt. Közismert tény, hogy egy fogalom több részmetaforában is megnyilvánul. Ezt tapasztalhatjuk meg például, amikor a fametafora Donald Tusknál a lombosodó Európára célozva jelenik meg, míg az egyetemistáknál a világfa képe merül föl többször népköltészeti ihletésröl tanúskodva. A hold és a nap metaforikus megjelenítése a fiataloknál és Göncz Árpád esetében is közös ősélményekhez kötődik. A férfiak és nők metaforahasználata azonos és különböző vonásokat is mutat. A különbség, ami nem meglepő, hogy a nőknél, és most elsősorban az egyetemistákra kell gondolni, egyegy szónoklatban hangsúlyos a természetre, népmesekincsre való hivatkozás.

A beszélők jobbára az ethosz-pátosz-logosz egységében alkotják meg szónoklataikat. Az egyetemisták és közéleti beszélők közötti különbség talán ott a legerőteljesebb, hogy mivel az egyetemisták beszédei nem nagyközönségnek íródnak, csupán a maguk korosztályát kívánják megszólítani szükebb körben, így a bizalmas jelleg, a személyes bevonódás sokkal inkább jellemzi őket, különösen a lányok egymáshoz intézett szövegeiben tapasztalható meg az érzelmesség és a családi mintakövetésböl eredő erkölcsi mag. Igazából jó olvasni, hogy hittel és odaadással készülnek összetett feladataikra. 
A fiúk is jelzik, hogy sokszor nem a logika érvényesül az életben, de ez nem is olyan nagy baj. Ök beszédeikben inkább hajlanak az iróniára, a tréfára, az élcelődésre. Az érett férfi, Mácsai Pál ünnepi beszéde is ironikus felütésében a meghökkentésre alapoz, mikor több évtizeddel korábbi élményeit így vezeti be: „Hölgyeim és uraim, néhány héttel ezelőtt, úgy tíz-tizenkét éves koromban, egy szép tavaszi napon a nagyszünetben megálltam az iskolaudvaron, és miközben uzsonnámat kigöngyöltem a papírszalvétából, eszembe jutott a kétezredik év" (Mácsai 1999). Egy szilveszteri beszédben ez nyilvánvalóan könnyebben elképzelhető, mint egy feszes protokollnak megfelelő felszólalásban, azonban Emma Watson sem idegenkedik a közvetlenség jegyeitől, hisz beszédében fölteszi provokáló kérdését: „Lehet, önök most azon tünődnek, hogy ki is ez a Harry Potter-lány. Mit keres az ENSZ emelvényén?” (Watson 2014).

Az egyetemisták természetesen könnyedebbek, meghittebbek, egymásnak beszélnek, a közéleti személyiségek felelőssége nagyobb, nem tudják és nem akarják elfordítani fejüket a kemény valóságtól, nagyobb távlatokba tekintenek. A beszédek hitelét sokszor a személyes bevonódás, személyes élettörténet adja. Ez nem hiányzik a legtöbb közéleti szereplő beszédéből sem: Göncz Árpád a börtönéveire, Oprah Winfrey, Emma Watson, Mácsai Pál gyerekkori emlékeire, Bán Zsófia egy kedves könyvének eltulajdonítására tér ki. Áder János $A$ haza minden elött jegyében beszél, a többes szám és a közönségre és közösségre való többszörös utalás is ennek érdekében történik, mindannyiunk nevében hajol meg Arany János és a nemzet nagysága előtt. Bán Zsófia az egész közösség által ismert kognitív metaforáknak ad sajátos köntöst, de beszédének aranyfedezetét a maga alkotta képanyag biztosítja, amelyben a szenvedély és az erkölcsi kiállás találkozik annak reményében, hogy ne a szegénység uralkodjon el, különös tekintettel arra, hogy „,a szegénység a tudás szegénysége” (Bán 2010).

\section{Irodalom}

Aczél Petra. 2009. Új retorika. Pozsony: Kalligram.

Adamikné Jászó Anna. 2014. A politikai beszéd és első politikai szónoklattanunk. In A politikai beszéd, szerk. dr. Raátz Judit-dr. Tóth Etelka. Budapest: Trezor Kiadó.

Áder János. 2017. Áder János köztársasági elnök beszéde az MTA Arany János-emlékévet megnyitó tudományos konferenciáján Nagyszalontán. https://www.keh.hu/ beszedek/2204-Ader_Janos_koztarsasagi_elnok_beszede_az_MTA_Arany_Janos_ emlekevet_megnyito_tudomanyos_konferenciajan_Nagyszalontan\&pnr=1 (2019. júl. 29.) 
Bán Zsófia. 2010. Van egy jó szava? In Galambos Rita et al. Dilemma - Disputa Demokrácia: Kézikönyv a vitakultúra fejlesztéséhez. 187-188. Demokratikus Ifjúságért Alapítvány. https://www.scribd.com/document/353924707/DilemmaDisputa-Demokracia (2019. nov. 3.)

Baranyiné Kóczy Judit. 2018. Mi a kulturális metafora? https://www.researchgate.net/ publication/322593772_Mi_a_kulturalis_metafora (2019. nov. 3.)

Bell, Colleen Bradley. 2015. Beszéd a Citibank női vezetők rendezvényén. https:// hu.usembassy.gov/hu/remarks-citibank-women-leaders-event-hu/ (2019. júl. 29.)

Bogyay Katalin. 2017. Beszéd a Nö a Partnerség Konferencián. https://ensz-newyork. mfa.gov.hu/assets/75/74/83/4e89f1c38b54995b391ccf9011b4cb86479ad66e.pdf (2019. nov. 3.)

Boros Emőke. 2001. Beszéd a második országos Kossuth-szónokversenyen. In A szónoki beszéd részei és a beszédfajták, szerk. A. Jászó Anna-Aczél Petra. 94-95. Budapest: Trezor Kiadó.

Dér Csilla Ilona. 2018. Nők a nyilvánosságban gendermegközelítésben. In Beszédnemek - nemek beszéde: Retorika a reformációtól napjainkig, szerk. Hujber SzabolcsPölcz Ádám. 13-18. Budapest: Magyar Nyelv és Kultúra Nemzetközi Társasága (MNYKNT)-ELTE Tanító- és Óvóképző Kar Magyar Nyelv és Irodalmi Tanszék.

Dósa Annamária. 2003. Beszéd a negyedik országos Kossuth-szónokversenyen. A modern retorikai bizonyitás, szerk. A. Jászó Anna-Aczél Petra. 149-150. Budapest: Trezor Kiadó.

Dudás Róbert Gyula. 2003. Beszéd a negyedik országos Kossuth-szónokversenyen. In A modern retorikai bizonyitás, szerk. A. Jászó Anna-Aczél Petra. 107-108. Budapest: Trezor Kiadó.

Földesi Norbert. 2001. Beszéd a második országos Kossuth-szónokversenyen. In A szónoki beszéd részei és a beszédfajták, szerk. A. Jászó Anna-Aczél Petra. 90-91. Budapest: Trezor Kiadó.

Gáti Magdolna. 2003. Beszéd a negyedik országos Kossuth-szónokversenyen. In A modern retorikai bizonyitás, szerk. A. Jászó Anna-Aczél Petra. 153-154. Budapest: Trezor Kiadó.

Göncz Árpád. 1999. Göncz Árpád beszéde az 51. Frankfurti Könyvvásár megnyitója alkalmából. http://www.frankfurt.matav.hu/magyar/live1.htm (2019. nov. 3.)

Huszár Ágnes. 2009. Bevezetés a gendernyelvészetbe. Budapest: Tinta Könyvkiadó.

Katona Edit. 2006. Metaforikus gondolkodás és anyanyelvi kompetencia. Hungarológiai Közlemények 37 (3): 24-43.

Katona Edit. 2011. Kognitív metaforák vizsgálata egyetemistáink szónoklataiban. Hungarológiai Közlemények 42 (1): 25-33.

Katona Edit. 2012. Anyanyelvi kompetencia - metaforikus kompetencia. In Diskursi manjinskih jezika, književnosti i kultura u jugoistočnoj i srednjoj Evropi: Zbornik radova. 139-153. Novi Sad: Filozofski fakultet. 
Katona Edit. 2016. „Ha férfi vagy, légy férfi”: A férfiasság kódjainak metaforikus megjelenési formái. Hungarológiai Közlemények 47 (2): 53-64.

Köble Hajnal. 2003. Beszéd a negyedik országos Kossuth-szónokversenyen. In A modern retorikai bizonyitás, szerk. A. Jászó Anna-Aczél Petra. 169-170. Budapest: Trezor Kiadó.

Mácsai Pál. 1999. Szilveszteri konferansz. http://www.revbiro.hu/1999szil.htm (2019. nov. 3.)

VI. Pál pápa. 1995. Levél a nőknek a Nők IV. Világkonferenciája alkalmából. https:// regi.katolikus.hu/konyvtar.php?h=77 (2019. nov. 1.)

Pölcz Ádám. 2018. Hogyan viszonyul a politika a nőkhöz?: Híres női szónokok. In Beszédnemek - nemek beszéde: Retorika a reformációtól napjainkig, szerk. Hujber Szabolcs-Pölcz Ádám. 19-29. Budapest: Magyar Nyelv és Kultúra Nemzetközi Társasága (MNYKNT)-ELTE Tanító- és Óvóképző Kar Magyar Nyelv és Irodalmi Tanszék.

Száraz László. 2003. Csalódott Püthagorasz: Beszéd a negyedik országos Kossuthszónokversenyen. In A modern retorikai bizonyitás, szerk. A. Jászó Anna-Aczél Petra. 98-99. Budapest: Trezor Kiadó.

Szontagh Pál. 2003. Hölgyek akkor és ma: Pályamű a negyedik országos Kossuthszónokversenyre. In A modern retorikai bizonyitás, szerk. A. Jászó Anna-Aczél Petra. 87-88. Budapest: Trezor Kiadó.

Szökrön Ágnes. 2018. Beszéd a 18. Kárpát-medencei Kossuth-szónokversenyen. 195-196. In Beszédnemek - nemek beszéde: Retorika a reformációtól napjainkig, Hujber Szabolcs-Pölcz Ádám szerk. Budapest: Magyar Nyelv és Kultúra Nemzetközi Társasága (MNYKNT)-ELTE Tanító- és Óvóképző Kar Magyar Nyelv és Irodalmi Tanszék.

Szőnyi László Gyula. 2001. Beszéd a második országos Kossuth-szónokversenyen. In A szónoki beszéd részei és a beszédfajták, szerk. A. Jászó Anna-Aczél Petra. 120-121. Budapest: Trezor Kiadó.

Tóth Gabriella. 2012. A stíluseszközök használatában megnyilvánuló gender alapú különbségek. http://filozofia.unideb.hu/na/vol2012_1/121_TG_Astil.pdf(2019.júl. 7.)

Tusk, Donald. 2017. Donald Tusk elnök beszéde az Európai Unió Parlamenti Elnökei Konferenciáján Rómában. https://www.consilium.europa.eu/hu/press/press-releases/ 2017/03/17/tusk-speech-conference-eu-parliaments-rome/ (2019. júl. 29.)

Watson, Emma. 2014. A nemek egyenlösége a férfiak ügye is. https://nokert.hu/ tue-20140923-1615/1102/1/nemek-egyenlosege-ferfiak-ugye-emma-watson-beszede Ford. Zelei Bori. (2019. nov. 1.)

Winfrey, Oprah. 2018. Oprah Winfrey beszéde a Golden Globe-gálán. http://goodstuff. hu/2018/01/08/oprah-winfrey-olyan-inspirativ-beszedett-mondott-a-golden-globeon-hogy-meg-evekig-idezni-fogjuk/ (2019. júl. 29.) 


\section{WHAT SHALL I CALL YOU? GENDER-BASED ANALYSIS OF METAPHOR USAGE IN ORATORY SPEECHES}

In our social life there are many occasions that call for delivering a speech. Speeches given at celebrations and other social events are often made with the intention to persuade or at least to impress. In my study I look into twenty oratory speeches: ten given by women and ten by men. Half of these were given at public forums, while the other half was delivered at the traditional Kossuth Oratory Contest organized for university students in Budapest. The objective of the research was to map the imagery sources of the metaphors used, on the one hand by public speakers and, on the other, by the students, and to see whether there were marked differences between the metaphoric features of their speeches. Special attention was paid to the question of whether the choice of metaphors was influenced by the fact that the speech was intended for an audience of the speakers' own gender. Other important points were whether the metaphorical character was the result of a wider context, cognitive based, or linguistic-stylistic, as well as of the rhetorical procedures it was integrated into the speeches.

Keywords: rhetorical situation, logos-pathos-ethos, cognitive metaphor

\section{KAKO DA TE ZOVEM? RODNA ANALIZA UPOTREBE METAFORE U BESEDNIŠTVU}

U društvenom životu postoji bezbroj prilika kada smo primorani da održimo nekakav govor. Govori koji su upriličeni povodom praznika ili raznih društvenih događaja, nastali su sa namerom da se pomoću njih utiče na publiku ili da se bar ostavi jak utisak. U studiji se analizira 20 besedničkih govora: njih je izgovorilo deset žena i deset muškaraca. Polovina ovih govora je održana na javnim forumima, dok je deset predstavljeno na tradicionalnom takmičenju iz besedništva studenata, nazvanom po Lajošu Košutu u Budimpešti. Cilj rada je da se ispita kakve metafore koriste javne ličnosti a kakve studenti, da li postoji značajna razlika između upotrebe pojmovnih slika kod pripadnika ženske i muške populacije, kod političara, javnih govornika i studenata. Poseban akcenat se stavlja na pitanje da li pol kojem je upućen govor, odnosno da li okolnost da je govor namenjen istom polu, utiče na izbor pojmovnih slika. Nije nevažna ni činjenica da li je metaforičnost rezultat šireg konteksta, da li se zasniva na kognitivnom pristupu ili poprima i jezičko-stilsku formu, kao i to kojim se retoričkim postupcima ugrađuju u govor.

Ključne reči: govorna situacija, rodna uloga, logos-patos-etos, kognitivna metafora 